\title{
Generation and validation of a floxed FosB mouse line
}

Authors: Yoshinori N. Ohnishi ${ }^{1,2}$, Andrew L. Eagle ${ }^{3}$, Yoko H. Ohnishi ${ }^{1,2}$, Michael E. Cahill ${ }^{2,4}$, Alexis J. Wirtz ${ }^{3}$, Alfred J. Robison ${ }^{3 *}$, Eric J. Nestler ${ }^{2 *}$

\section{Affiliations:}

1Department of Pharmacology, Kurume University School of Medicine, Kurume, Fukuoka, Japan

${ }^{2}$ Department of Neuroscience and Friedman Brain Institute, Icahn School of Medicine at Mount Sinai, New York, NY, USA

${ }^{3}$ Department of Physiology, Michigan State University, East Lansing, MI, USA.

${ }^{4}$ Department of Comparative Biosciences, University of Wisconsin at Madison, Madison, WI, USA

*Both authors contributed equally to this work and can be contacted at: Alfred Robison <robiso45@msu.edu> and Eric Nestler <eric.nestler@mssm.edu>. 


\section{Abstract:}

Expression of the FosB gene has been studied extensively in many fields using a variety of tools. However, previous techniques have had a variety of caveats, from potential off-target effects (e.g., overexpression of FosB, $\Delta$ FosB, or a dominant negative mutant of JunD, termed $\Delta$ JunD) or confounding developmental effects (e.g., the constitutive FosB knockout mouse). Therefore, we sought to create a floxed FosB mouse line that will allow true silencing of the FosB gene with both spatial and temporal control. Here, we detail the cloning strategy, production, and validation of the floxed FosB mouse. We demonstrate methodology for breeding and genotyping, and show that viral-mediated expression of Cre recombinase in a targeted, discrete brain region ablates expression of the FosB gene in floxed but not wild type mice. Thus, the floxed FosB mouse presented here represents an important new tool for the continued investigation of this critical gene. 


\section{Introduction}

FosB is an activity-dependent immediate early gene whose expression is enriched in the brain. It encodes transcription factors that combine with Jun-family proteins to form AP-1 complexes that bind DNA and regulate the transcription of a host of gene targets. Expression of the FosB gene has been studied extensively in the fields of addiction (Robison and Nestler, 2011), mood disorders (Manning et al., 2017), natural reward (Teegarden et al., 2008; Pitchers et al., 2010), learning (Eagle et al., 2015), Parkinson's disease and related syndromes (Dietz et al., 2014; Feyder et al., 2016), epilepsy (Giordano et al., 2015), bone density (Rowe et al., 2012), and cataracts (Kelz et al., 2000). Its role in long-term behavioral adaptations underlying both maladaptive and normal forms of learning, reward, and other functions has been speculated to arise from the unique ability of its protein products to modulate long-lasting changes in gene expression.

In the rodent brain, FosB gene products are spliced to produce two major mRNA variants: a full-length FosB variant that results in a 338-amino acid protein, and an alternative variant that introduces a premature stop codon to produce a 237 -amino acid c-terminal truncation termed $\Delta$ FosB (Nestler, 2015). The C-terminal region of FosB missing in the $\Delta$ FosB isoform contains a portion of the putative transactivation domain as well as two degron domains that target the full-length protein for proteosomal degradation (Carle et al., 2007). Thus, the $\Delta$ FosB isoform is uniquely stable, with a half-life in vivo of approximately eight days (UleryReynolds et al., 2009), making it particularly well-suited to mediate long-term changes in gene expression.

A variety of tools have been used to interrogate the function of the FosB gene in the brain. Multiple mouse lines have been used to overexpress the $\Delta$ FosB isoform in select neuronal populations, establishing that $\Delta$ FosB expression in D1-type medium spiny neurons of the nucleus accumbens (NAc) is sufficient to increase the rewarding properties of multiple drugs (Kelz et al., 1999; Zachariou et al., 2006) as well as to mediate stress resilience (Vialou et al., 
2010; Ohnishi et al., 2015). Viral vectors overexpressing $\triangle F$ osB in all NAc neurons have been used to confirm these results. In order to establish the necessity of $\Delta$ FosB expression for these processes, most studies have relied on overexpression of mutant forms of the requisite binding partners, Jun family proteins termed $\Delta J u n D$ or $\Delta c$-Jun, which lack their $\mathrm{N}$-terminal transactivation domains and presumably act as dominant negative antagonists in vivo (Peakman et al., 2003; Zachariou et al., 2006; Vialou et al., 2010). The use of transgenic mice expressing these inhibitors, and of Cre recombinase-dependent viral vectors, has allowed celltype specific inhibition of $\Delta$ FosB-dependent transcriptional activity, but questions remain as to whether $\Delta$ JunD has off-target effects and the extent to which it is able to inhibit the entire cellular pool of $\Delta$ FosB.

FosB knockout mouse lines have been produced as well (Brown et al., 1996; Yutsudo et al., 2013). Consistent with the overexpression studies cited above, one of the lines shows increased susceptibility to depression-like behaviors (Yutsudo et al., 2013). On the other hand, a different knockout line shows enhanced, not reduced, sensitivity to cocaine (Hiroi et al., 1997), the opposite of what has been observed with the more selective transgenic and viral tools. The whole-body nature of the knockout animal by definition suggests that any behavioral effects in the adult may arise from altered development. Indeed, the FosB knockout mouse lines show either defects in maternal behavior (Brown et al., 1996) or a malformed dentate gyrus (Yutsudo et al., 2013). As well, the knockout mice cannot provide information on the site of action of FosB gene products within any given brain region or cell type. Therefore, we sought to create a floxed FosB mouse line. Such a line, when mated with Cre-recombinase expressing mouse lines or in combination with viral vectors encoding Cre, will allow true knockout of the FosB gene with both spatial and temporal control, and without the caveats of non-specific inhibition of other Fosfamily proteins or the constitutive knockout.

\section{Construction of targeting vector}


We cloned the $F R T$-neo cassette-FRT-loxP region from a neo expressing DNA vector and fragments of the FosB gene between the Nhel site of intron 1 and the Scal site in intron 3 (including a loxP sequence at the Scal site) into the pENTR/D-TOPO vector (Invitrogen, Massachusetts, USA). After DNA sequencing of the cloning products, we combined both products into the FosB gene cloning vector with tyrosine kinase expressing cassettes at both ends of the FosB gene construct (Figure 1A). The $F R T$-neo cassette-FRT-loxP region was then inserted into the Nhel site of intron 1 of the FosB gene. The second loxP was inserted at the Scal site in intron 3. These steps made use of the following cloning primers:

$\underline{\text { Cloning primers for neo cassette }}$

FRTneoUT; 5'-caccGCTAGCctgccataactagtccttgGAAGTTCCTATTCTCTAGAAAGTATAGGAACttcGATGAGCTTTATCCAAACC-3', loxPFRTneoL; 5'-CATATGataacttcgtatagcatacattatacgaagttatGAAGTTCCTATACTTTCTAGAGAATAGGAACttcGGCGCGCCGCTCGCGAAAGCTTGGGC-3’

Cloning primers for second loxP site

FLOXUT; 5'-caccCATATGgAtagcCTACGGAGAGGCAGCCAGGTGGTCTCTAAAAGGTC-3', FLOXL; 5'-AGTACTataacttcgtatagcatacattatacgaagttatCTGCCTTAAAGGGCAGAAGGGGGCATTGTAGCTCACTGAGTGAAGGAGATTG-3’

\section{Genotyping of ES cells}

We performed nested genomic PCR for confirmation of homologous recombination around the FosB gene in ES cells (Figure 1A and B) using Phire Taq (NEB, Massachusetts, USA). Additionally, we examined whether the homologous recombination covered the loxP site in intron 3 by PCR with a separate primer set (Figure $1 \mathrm{~A}$ and $\mathrm{C}$ ). These steps made use of the following primers: 
$\underline{1^{\text {st }} \text { PCR for } 5 \text { ' site (size } 5900 \mathrm{bp} \text { ) }}$

5FB1stU; 5'-AGAGGTAGAGGTCATCCTG-3'

3FB1stL; 5'-GATTGCACGCAGGTTCTCCG-3'

Nested PCR for 5' site (size 3434 bp)

5FB2ndU; 5'-CCAGGACTTCACACATGCT-3'

5FB2ndL; 5'-AGAGCGAGGGAAGCGTCTACCTA-3'

1st PCR for 3' site (size 8936 bp)

3FB1stU; 5'-GAGCCACCTTCTTCTCCAA-3'

3FB1stL; 5'-CAAAACCTCGCCTCCAAGT-3'

Nested PCR for 3' site (size 7243 bp)

3FB2ndU; 5'-TGGCGCGTCCAATCAATTG-3'

3FB2ndL; 5'-TCTCTGCGTTGGAGCAGTA-3'

$\underline{\text { PCR for loxP in intron } 3 \text { (size } 231 \mathrm{bp} \text { or } 197 \mathrm{bp} \text { ) }}$

2ndLOXPU; 5'-CAATGCCCCCTTCTGCCCTTTA-3'

2ndLOXPL; 5'-TGCTACTTGTGCCTCGGTTTCC-3'

\section{Generation of floxed FosB mice}

Floxed FosB embryonic stem (ES) cell clones with correct homologous recombination were injected into blastocysts prepared from C57BL/6J mice. The floxed FosB allele contained two loxP sites in intron 1 and 3 , and an $F R T$-neo- $F R T$ cassette next to loxP in intron 1 (Figure 1). After Cre recombination, the FosB gene will lose exons 2 and 3 (Figure 2A), which include the $\mathrm{N}$-terminal transactivation domain and basic region and most of the leucine zipper domain, regions with essential roles in DNA binding, transactivation, and dimerization with Jun family proteins. Neomycin-resistant gene cassettes for positive selection were removed by Flp/FRTmediated recombination through breeding with FLPo transgenic mice. This work was conducted with the Mouse Genetics and Gene Targeting (MGGT) CoRE at Mount Sinai. 


\section{Genotyping and breeding of floxed FosB mice}

Mice were back-crossed with wild-type C57BL/6J obtained from Jackson Labs (Bar Harbor, ME, USA) for at least four generations. PCR genotyping was performed on tail-derived DNA using the REDExtract-N-Amp kit (Sigma-Aldrich, St. Louis, MO, USA) with the following thermocycler protocol:

1. $95^{\circ} \mathrm{C} \quad 2$ minutes

2. $95^{\circ} \mathrm{C} 30$ seconds

3. $55^{\circ} \mathrm{C} 30$ seconds Repeat 34 cycles

\section{4. $72^{\circ} \mathrm{C} 90$ seconds}

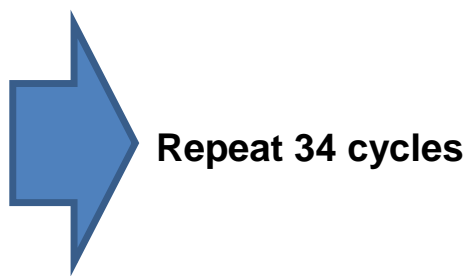

5. $72^{\circ} \mathrm{C} \quad 5$ minutes

6. $4^{\circ} \mathrm{C}$ hold

PCR primers were as follows:

FB loxPu sequence; 5' - GCT GAA GGA GAT GGG TAA CAG - 3'

LIPz sequence; 5' - AAG CCT GGT GTG ATG GTG A - 3'

LNEo1 sequence; 5' - AGA GCG AGG GAA GCG TCT ACC TA - 3'

This protocol produces PCR products of $359 \mathrm{bp}$ in wild type mice, $397 \mathrm{bp}$ in floxed FosB mice, and both bands in heterozygous mice (Figure 2B). We maintain a colony of these mice by breeding heterozygous animals, and use homozygous floxed and wild type littermate progeny in all experiments.

\section{Validation of floxed FosB mice}

In order to determine whether expression of Cre recombinase in floxed Fos $B$ mice effectively eliminates FosB gene expression, we mated floxed FosB mice with Rosa26 ${ }^{\text {eGFP-L10a }}$ reporter mice (Jackson Labs, stock \#024750). This line produces enhanced green fluorescent protein in the presence of Cre recombinase. We then stereotaxically injected herpes simplex 
virus expressing Cre (HSV-Cre; MIT Viral Vector Core, Boston, MA, USA) into the hippocampus of adult male wild type and floxed FosB mice carrying this reporter as previously described (Eagle et al., 2015). 48 hours later, mice were euthanized by chloral hydrate overdose and transcardially perfused with ice cold $10 \%$ formalin to fix brain tissue. Brains were post-fixed in $10 \%$ formalin for 24 hours at $4^{\circ} \mathrm{C}$, then cryoprotected in $30 \%$ sucrose. Coronal sections (35 $\left.\mu \mathrm{m}\right)$ were prepared on a freezing microtome and then stored in PBS with $0.1 \%$ sodium azide. Immunofluorescent labeling was performed using a goat anti-GFP antibody (Abcam, ab5450, 1:1000) and a rabbit anti-FosB antibody (Cell Signaling, 5G4; $1: 500$ ), with secondary antibodies from Jackson Immunoreagents.

We observed that HSV-Cre-mediated eGFP had a broad neuronal expression profile throughout the hippocampus in both wild type and floxed FosB mice (Figure 2C). In the CA1 region of wild type mice, about $10 \%$ of HSV-Cre transduced neurons were found to be FosBpositive, consistent with our previous results (Eagle et al., 2015). However, in floxed FosB mice, we found that less than $2 \%$ of HSV-Cre transduced cells had a detectable FosB expression, an almost total abrogation of FosB gene activity (Figure $3 A$ and $B ; t=3.603 ; d f=10$ ). These data demonstrate that the floxed FosB mouse does not express the FosB gene in the presence of Cre recombinase, validating this mouse line for investigation of the role of FosB gene products in various cellular and behavioral phenotypes.

In order to ensure that these results would generalize to other viral methods and brain regions, Floxed FosB mice were given intra-NAc injections of AAV-Cre-GFP or AAV-GFP (University of North Carolina Vector Core, Chapel Hill, NC, USA). Three weeks later, when transgene expression is maximal, mice were given a single IP dose of cocaine $(20 \mathrm{mg} / \mathrm{kg}$; Sigma Aldrich, St. Louis, MO, USA). Animals were euthanized 90 min later when FosB induction is known to be maximal, and immunofluorescence was performed as above. Induction of FosB was dramatically reduced in animals expressing Cre (Figure 3C). 


\section{Discussion}

Here, we describe the production and validation of a floxed FosB mouse line, a novel tool for exploration of the role of FosB gene products in a variety of contexts. Future experiments may involve mating this line with multiple Cre driver lines to assess the roles of FosB gene expression in specific cell types. Of primary interest are driver lines allowing selective FosB deletion in D1-type or D2-type medium spiny neurons (Lobo et al., 2013), and lines allowing investigation of the role of the FosB gene in hippocampal pyramidal cells (Eagle et al., 2015). As we demonstrate here, the use of viral vectors to express Cre and inhibit FosB gene expression in a spatially and temporally restricted manner will also be a viable approach. Moreover, the use of retrograde viruses expressing Cre will allow circuit-specific investigation of the cellular role of FosB gene expression.

A critical limitation to investigation of the role of $\Delta \mathrm{FosB}$ in cell function and behavior has been the limited ability to identify target genes. Early gene expression and microarray analyses revealed many candidates (McClung and Nestler, 2003), but poor antibodies have made unbiased ChIP sequencing experiments difficult. By combining our floxed FosB mouse with Cre driver lines and reporter lines allowing expression of GFP-tagged ribosomal subunits, translating ribosome affinity purification (TRAP) (Heiman et al., 2014) may be able to reveal genes whose expression is altered when FosB is silenced. Moreover, combining viral GFP-Cre transduction of floxed FosB and wild type mice with immunofluorescent detection of expression of candidate target gene products will allow in vivo, cell type-specific validation of such targets. Thus, the floxed FosB mice presented here represent an exciting new tool for the continued investigation of this critical gene. 


\section{Figure Legends}

Figure 1: FosB targeting and construct cloning strategy. A) Global map of the FosB gene and targeting gene construct. Colored bars represent products of nested PCR or genotyping PCR. B) $1 \%$ agarose gel of DNA products of nested genomic PCR of various ES cells (numbered at top) between the 5' outside region of the targeting construct area and its inside region (left) and nested genomic PCR between the 3' outside region of the targeting construct area and its inside region (right). Black arrows indicate expected bands with given correct homologous recombination. C) $4 \%$ agarose gel of DNA products of PCR around the second loxP region. Successful homologous recombination around second loxP region results in two bands, $231 \mathrm{bp}$ and $197 \mathrm{bp}$, indicated by black arrows.

Figure 2: Floxed FosB mouse recombination strategy and genotyping. A) Cre-mediated recombination of the floxed FosB gene results in removal of exons 2 and 3, functionally knocking out expression of the gene. B) $2 \%$ agarose gel of PCR products from tail-derived DNA used to genotype floxed FosB mice. Wild type mice have a product of 359 bp (white arrow), floxed FosB mice have a product of 397 bp (black arrow), and heterozygous mice have both bands.

Figure 3: Floxed FosB mouse in vivo validation. A) Immunofluorescent labeling of GFP expressed in HSV-Cre-transduced neurons (Green) and FosB (red) in hippocampus of wild type (WT) or floxed FosB mice. White arrows indicate FosB-positive transduced cells in the WT mouse which are absent in the floxed FosB mouse. B) Quantification of data from (A) demonstrating Cre-dependent knockout of FosB protein expression in the floxed FosB mouse. Error bars indicate SEM, $n=6$ mice per group, ${ }^{*}: p<0.005$ compared to WT. C) Immunofluorescent labeling of GFP expressed in AAV-GFP or AAV-GFP-Cre-transduced neurons (Green) and FosB (red) in nucleus accumbens of floxed FosB mice 90 minutes after 
bioRxiv preprint doi: https://doi.org/10.1101/179309; this version posted August 22, 2017. The copyright holder for this preprint (which was not certified by peer review) is the author/funder, who has granted bioRxiv a license to display the preprint in perpetuity. It is made available under aCC-BY-NC-ND 4.0 International license.

acute cocaine exposure (i.p., $20 \mathrm{mg} / \mathrm{kg}$ ). Yellow arrows indicate GFP-Cre-transduced cells lacking FosB, blue arrows indicate GFP-transduced cells which continue to express FosB. 


\section{Literature Cited}

Brown JR, Ye H, Bronson RT, Dikkes P, Greenberg ME (1996) A defect in nurturing in mice lacking the immediate early gene fosB. Cell 86:297-309.

Carle TL, Ohnishi YN, Ohnishi YH, Alibhai IN, Wilkinson MB, Kumar A, Nestler EJ (2007) Proteasomedependent and -independent mechanisms for FosB destabilization: identification of FosB degron domains and implications for DeltaFosB stability. Eur J Neurosci 25:3009-3019.

Dietz DM, Kennedy PJ, Sun H, Maze I, Gancarz AM, Vialou V, Koo JW, Mouzon E, Ghose S, Tamminga CA, Nestler EJ (2014) DeltaFosB induction in prefrontal cortex by antipsychotic drugs is associated with negative behavioral outcomes. Neuropsychopharmacology 39:538-544.

Eagle AL, Gajewski PA, Yang M, Kechner ME, Al Masraf BS, Kennedy PJ, Wang H, Mazei-Robison MS, Robison AJ (2015) Experience-Dependent Induction of Hippocampal DeltaFosB Controls Learning. J Neurosci 35:13773-13783.

Feyder M, Sodersten E, Santini E, Vialou V, LaPlant Q, Watts EL, Spigolon G, Hansen K, Caboche J, Nestler EJ, Fisone $G$ (2016) A Role for Mitogen- and Stress-Activated Kinase 1 in L-DOPA-Induced Dyskinesia and FosB Expression. Biol Psychiatry 79:362-371.

Giordano C, Vinet J, Curia G, Biagini G (2015) Repeated 6-Hz Corneal Stimulation Progressively Increases FosB/DeltaFosB Levels in the Lateral Amygdala and Induces Seizure Generalization to the Hippocampus. PLoS One 10:e0141221.

Heiman M, Kulicke R, Fenster RJ, Greengard P, Heintz N (2014) Cell type-specific mRNA purification by translating ribosome affinity purification (TRAP). Nat Protoc 9:1282-1291.

Hiroi N, Brown JR, Haile CN, Ye H, Greenberg ME, Nestler EJ (1997) FosB mutant mice: loss of chronic cocaine induction of Fos-related proteins and heightened sensitivity to cocaine's psychomotor and rewarding effects. Proc Natl Acad Sci U S A 94:10397-10402.

Kelz MB, Kuszak JR, Yang Y, Ma W, Steffen C, Al-Ghoul K, Zhang YJ, Chen J, Nestler EJ, Spector A (2000) DeltaFosB-induced cataract. Invest Ophthalmol Vis Sci 41:3523-3538.

Kelz MB, Chen J, Carlezon WA, Jr., Whisler K, Gilden L, Beckmann AM, Steffen C, Zhang YJ, Marotti L, Self DW, Tkatch T, Baranauskas G, Surmeier DJ, Neve RL, Duman RS, Picciotto MR, Nestler EJ (1999) Expression of the transcription factor deltaFosB in the brain controls sensitivity to cocaine. Nature 401:272-276.

Lobo MK et al. (2013) DeltaFosB induction in striatal medium spiny neuron subtypes in response to chronic pharmacological, emotional, and optogenetic stimuli. J Neurosci 33:18381-18395.

Manning CE, Williams ES, Robison AJ (2017) Reward Network Immediate Early Gene Expression in Mood Disorders. Front Behav Neurosci 11:77.

McClung CA, Nestler EJ (2003) Regulation of gene expression and cocaine reward by CREB and DeltaFosB. Nat Neurosci 6:1208-1215.

Nestler EJ (2015) FosB: a transcriptional regulator of stress and antidepressant responses. Eur J Pharmacol 753:66-72.

Ohnishi YN, Ohnishi YH, Vialou V, Mouzon E, LaPlant Q, Nishi A, Nestler EJ (2015) Functional role of the $\mathrm{N}$-terminal domain of DeltaFosB in response to stress and drugs of abuse. Neuroscience 284:165-170.

Peakman MC, Colby C, Perrotti LI, Tekumalla P, Carle T, Ulery P, Chao J, Duman C, Steffen C, Monteggia L, Allen MR, Stock JL, Duman RS, McNeish JD, Barrot M, Self DW, Nestler EJ, Schaeffer E (2003) Inducible, brain region-specific expression of a dominant negative mutant of c-Jun in transgenic mice decreases sensitivity to cocaine. Brain Res 970:73-86.

Pitchers KK, Frohmader KS, Vialou V, Mouzon E, Nestler EJ, Lehman MN, Coolen LM (2010) DeltaFosB in the nucleus accumbens is critical for reinforcing effects of sexual reward. Genes Brain Behav 9:831-840. 
Robison AJ, Nestler EJ (2011) Transcriptional and epigenetic mechanisms of addiction. Nat Rev Neurosci 12:623-637.

Rowe GC, Vialou V, Sato K, Saito H, Yin M, Green TA, Lotinun S, Kveiborg M, Horne WC, Nestler EJ, Baron $R$ (2012) Energy expenditure and bone formation share a common sensitivity to AP-1 transcription in the hypothalamus. Journal of bone and mineral research : the official journal of the American Society for Bone and Mineral Research 27:1649-1658.

Teegarden SL, Nestler EJ, Bale TL (2008) Delta FosB-mediated alterations in dopamine signaling are normalized by a palatable high-fat diet. Biol Psychiatry 64:941-950.

Ulery-Reynolds PG, Castillo MA, Vialou V, Russo SJ, Nestler EJ (2009) Phosphorylation of DeltaFosB mediates its stability in vivo. Neuroscience 158:369-372.

Vialou V et al. (2010) DeltaFosB in brain reward circuits mediates resilience to stress and antidepressant responses. Nat Neurosci 13:745-752.

Yutsudo N, Kamada T, Kajitani K, Nomaru H, Katogi A, Ohnishi YH, Ohnishi YN, Takase K, Sakumi K, Shigeto H, Nakabeppu Y (2013) fosB-null mice display impaired adult hippocampal neurogenesis and spontaneous epilepsy with depressive behavior. Neuropsychopharmacology 38:895-906.

Zachariou V, Bolanos CA, Selley DE, Theobald D, Cassidy MP, Kelz MB, Shaw-Lutchman T, Berton O, SimSelley LJ, Dileone RJ, Kumar A, Nestler EJ (2006) An essential role for DeltaFosB in the nucleus accumbens in morphine action. Nat Neurosci 9:205-211. 


\section{Figure 1}

A fosB gene

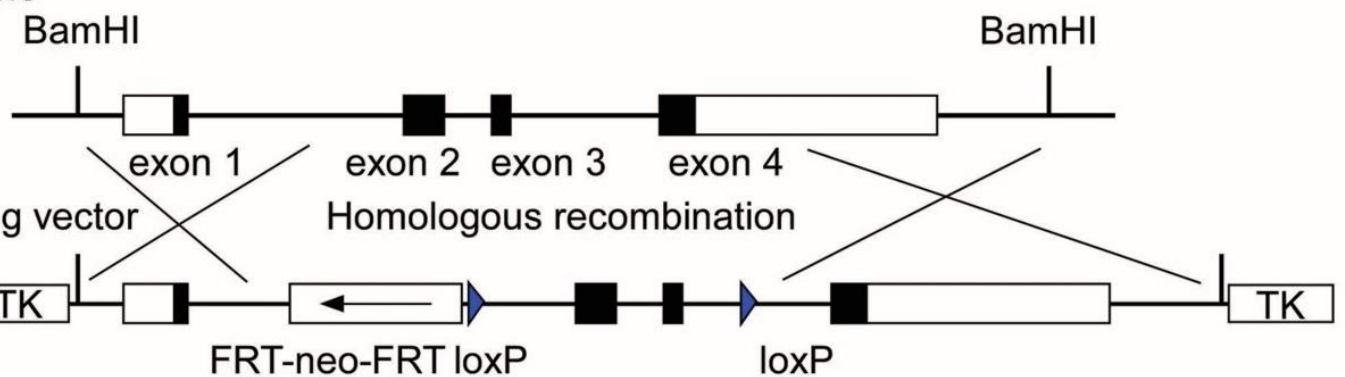

Targeted allele
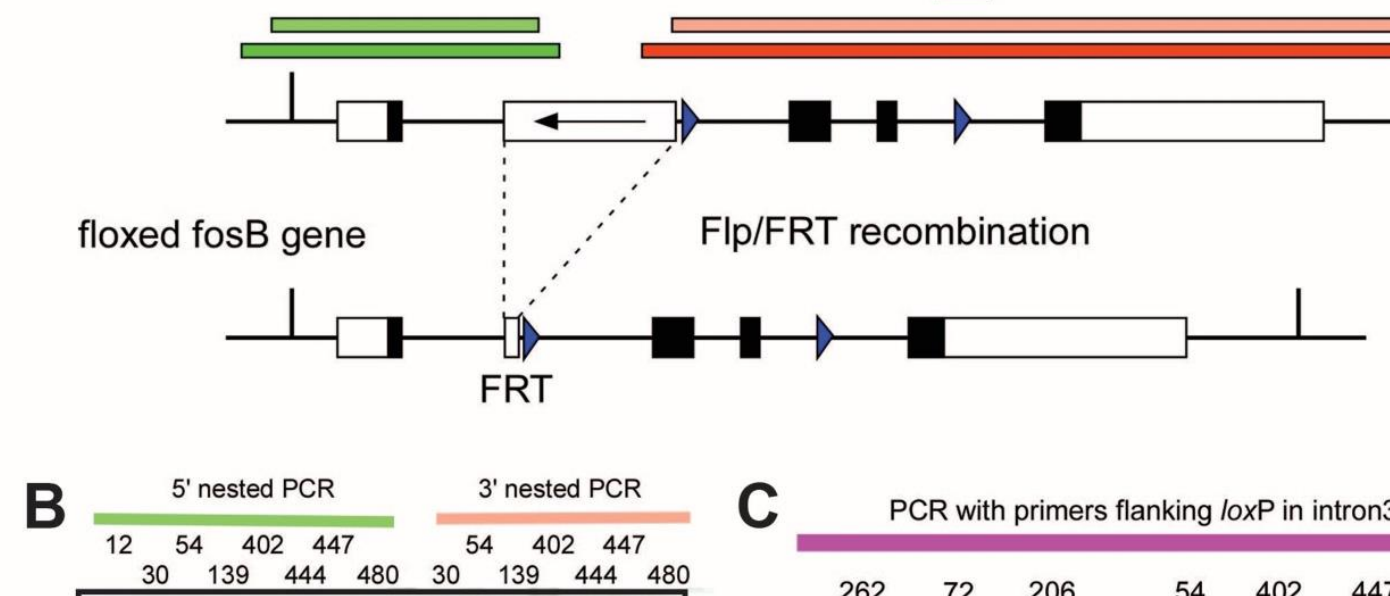

C

\begin{tabular}{l} 
PCR with primers flanking loxP in intron3 \\
\hline
\end{tabular}
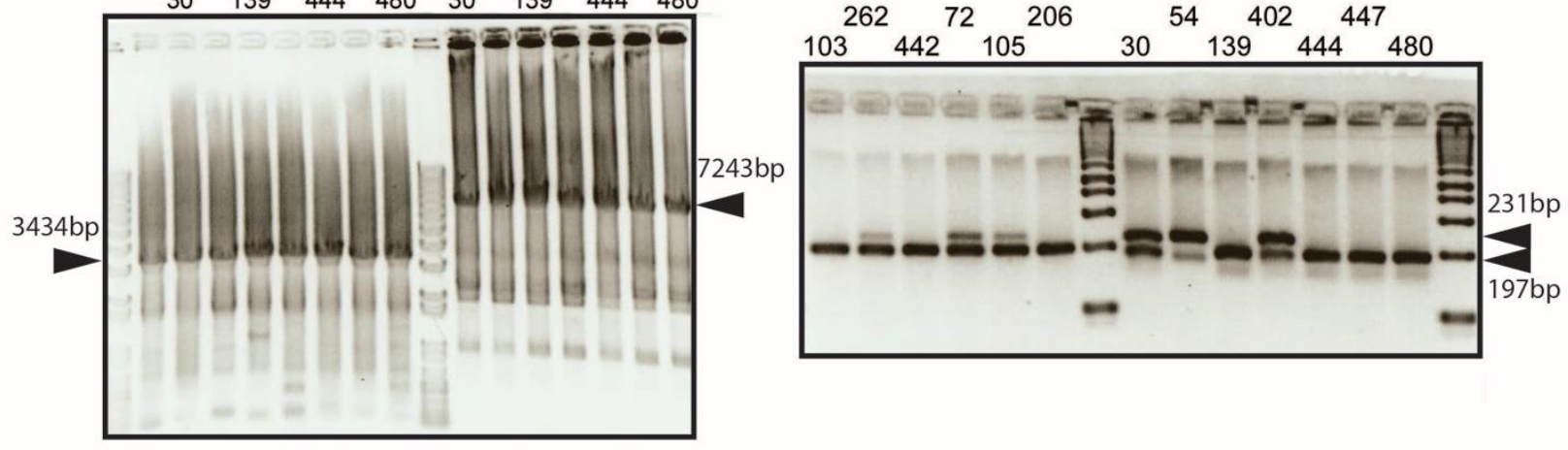
Figure 2
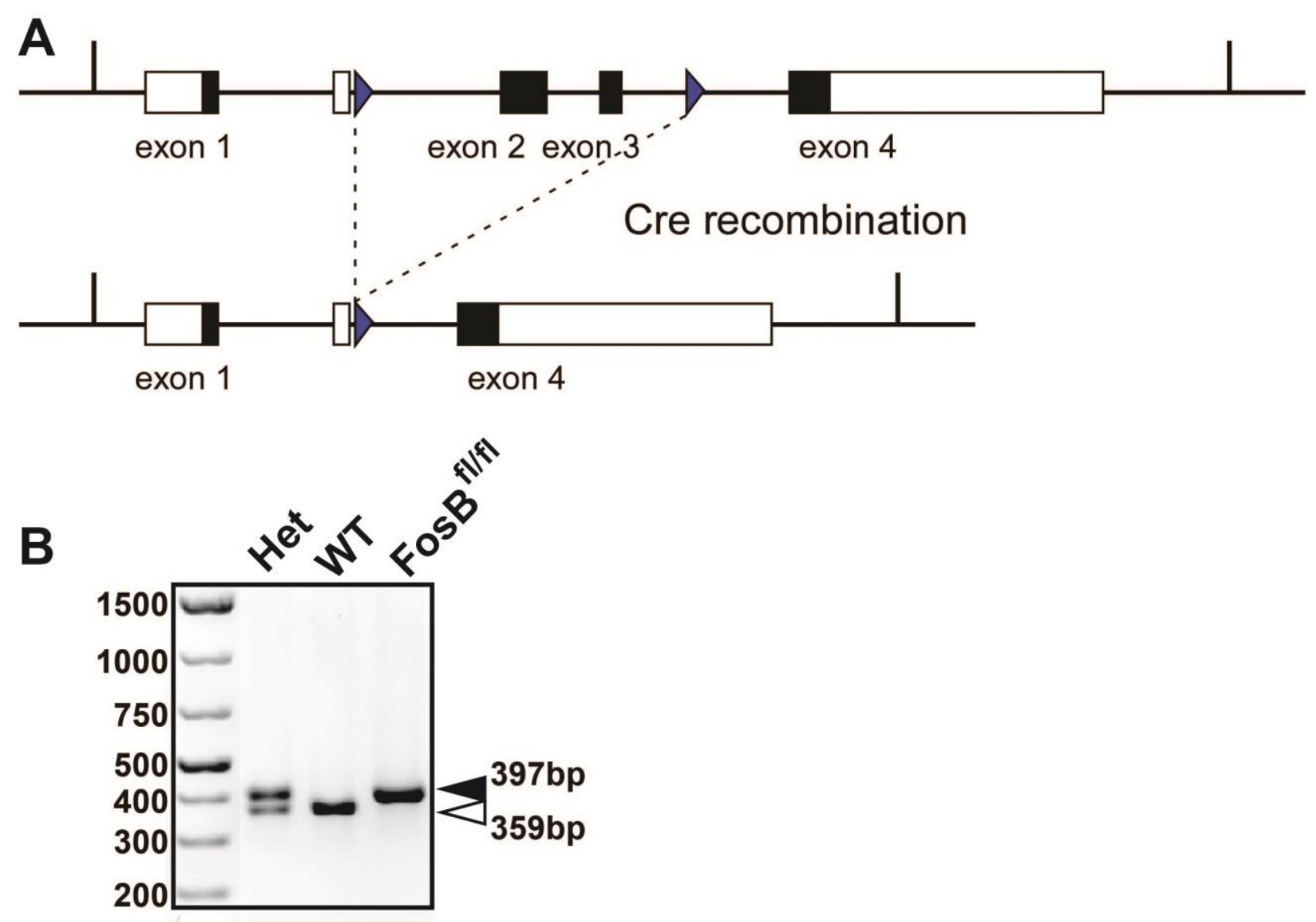
Figure 3

A

Hippocampus

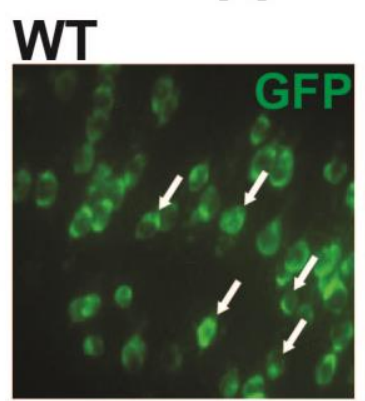

Floxed FosB
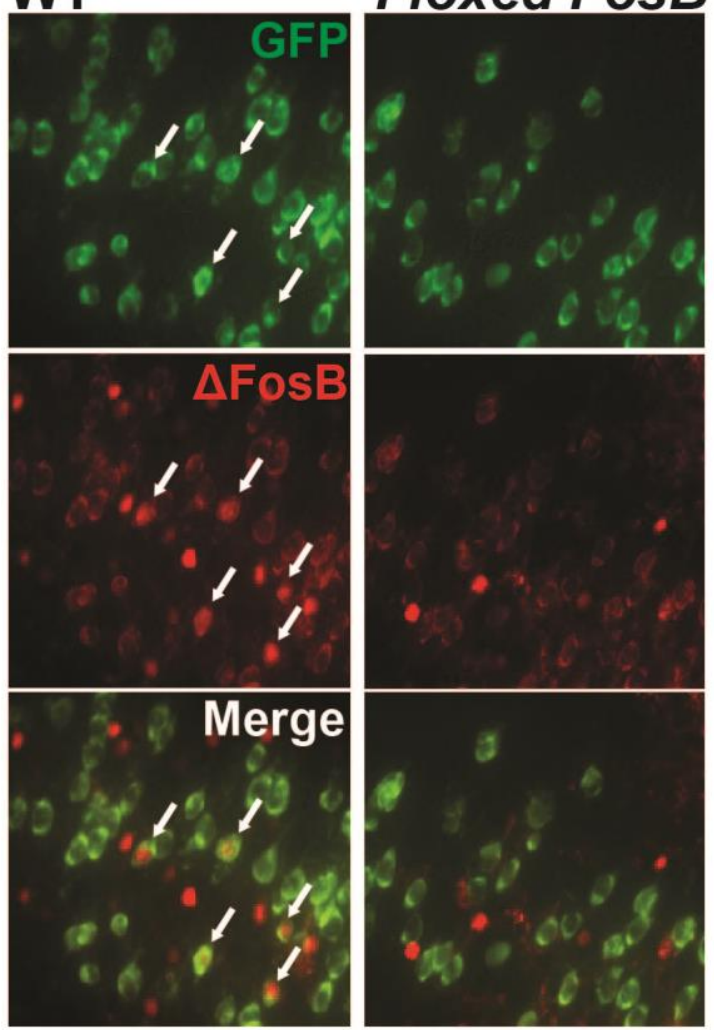

B
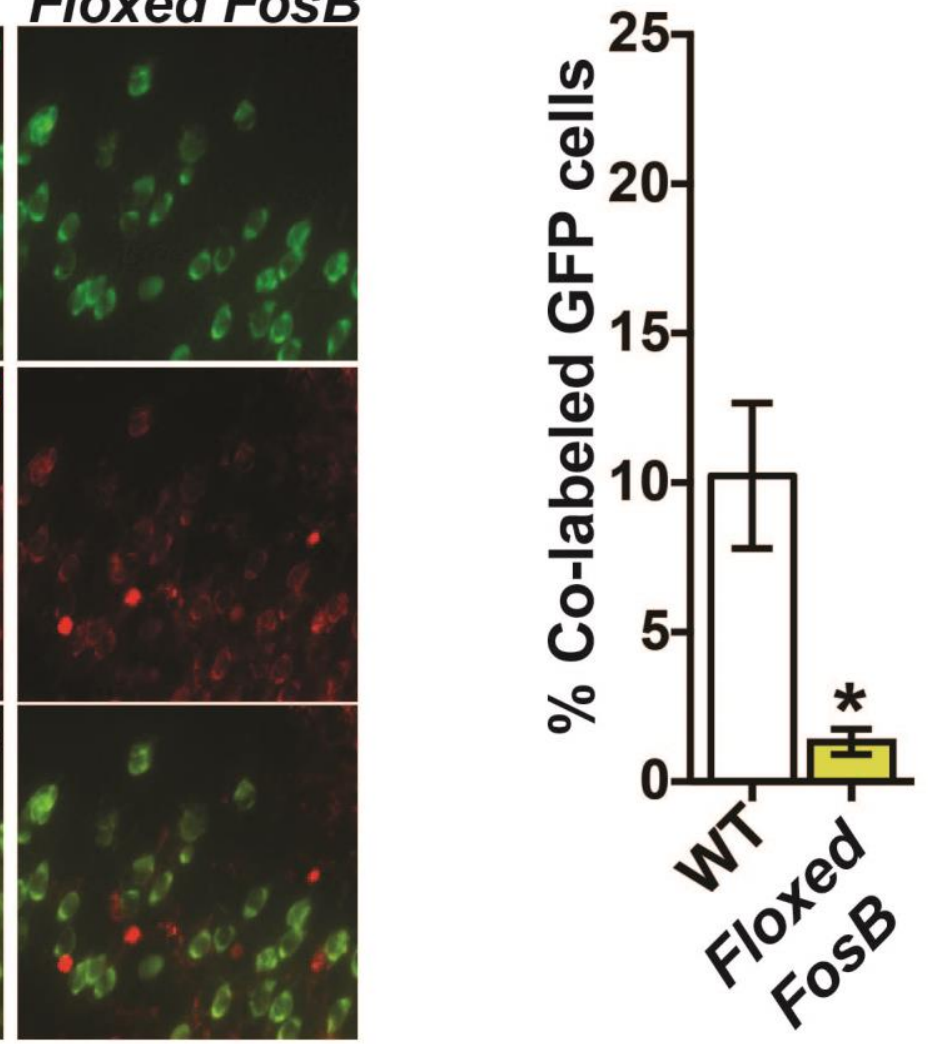

C Nucleus Accumbens

GFP

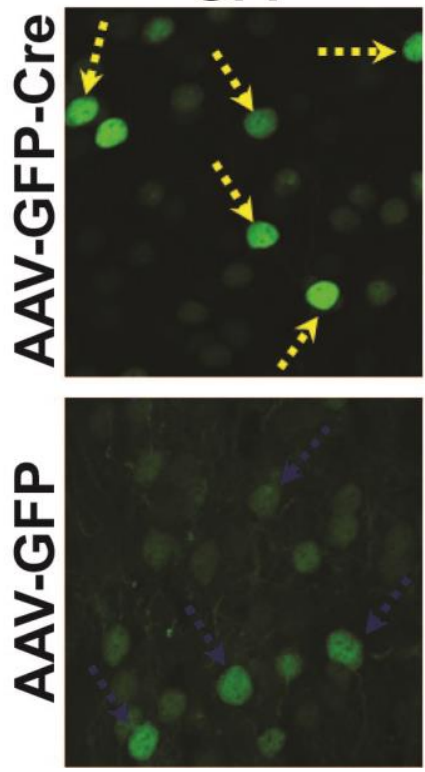

$\Delta$ FosB
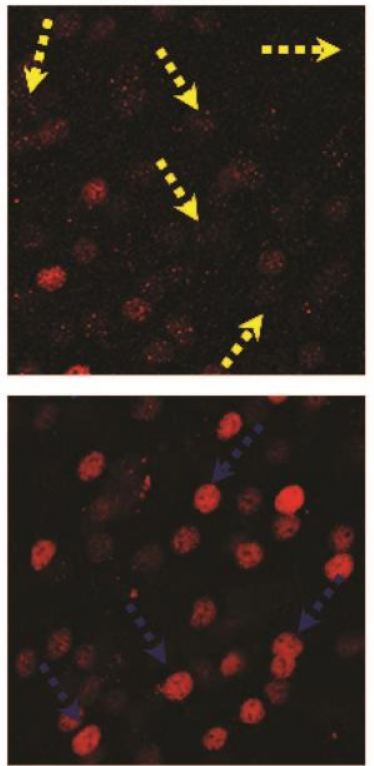